\title{
Pneumatikus munkahengerek alkalmazás-specifikus vizsgálata
}

\author{
Dr. Szaladnya Sándor, egyetemi tanár - Telek Péter, doktorandusz
}

\section{Summary}

Novadays the pneumatic systems are applied in several fields of the Industry. Against numerous advantages (cheaper, more accurate than the electronic systems, etc.), the matematical description of this systems is very complicated task because of the properties of the operating fluide. Our purpose was to create a new method which helps to calculate the piston movement of pneumatic cylinder exactly. The applicabelity of the new method was examined in a special field, the operate of opening and closing devices of solid and bulk materials storage silos. Results of this examination are movement-time and velocity-time functions which render determine possible the exact time of opening and closing process and the exact quantity of the flew material.

\section{Munkahengerek müködésvizsgálata}

Napjainkban, az automatizálás egyre erősebb térhódítása miatt, az ipar minden területén elötérbe kerül a pneumatikus rendszerek alkalmazása. Számos előnyével szemben (pl. jobban elviseli a környezeti hatásokat, olcsóbb, megbízhatóbb mint az elektronikus rendszerek elemei), legnagyobb hátránya az, hogy a pneumatikus munkahengerekben lejátszódó folyamatok az energiát hordozó közeg viselkedése miatt bonyolultak. Mivel a levegő összenyomható közeg, nyomása és sürüsége változik. A pneumatikus rendszerekben minden elem (szelepek, vezetékek, stb.), amelyen a levegő átáramlik nyomásváltozást okoz. $\mathrm{Az}$ egyszerübb elemek esetében ez a nyomásesés könnyen számítható, vagy gyakorlati mérésekkel megállapítható, viszont a munkahenger esetében, mivel itt megy végbe az energiaátalakítás, a számítások bonyolultabbak. A rendszer kezelhetősége érdekében a matematikai modell felállítása során bizonyos tényezök hatását elhanyagoljuk, vagy csak közelítő mértékben vesszük figyelembe, de az ebből adódó hiba mértékét utólag (például kísérletekkel) ellenőrizni kell. A mechanikai modell - az [1].irodalom alapján - egy kétoldali müködésü munkahenger, a hengertereket felváltva müködtetjük, s az egyszerüsités érdekében, a csatlakozó pontokhoz kapcsolódó szükítésekkel számolunk. A hőtani vizsgálatok során a rendszert 
adiabatikusnak tekintjük és elhanyagoljuk a munkahenger esetleges felmelegedéséből származó hőátadást a környezetnek. A modell két, egymástól elhatárolt részböl áll, amelynél a vizsgált helyzetben, az egyik részben csak beáramlás, a másik részben csak kiáramlás történik. Az alapegyenletekböl kiindulva (energiaegyenlet, Euler-egyenlet, mozgásegyenlet) - nyitott rendszert, és instacionárius esetet feltételezve meghatározzuk a nyomásváltozást, illetve a tömegáramlást.

$$
\begin{aligned}
& \text { nyomásváltozás: 1.hengertér } \quad \frac{\mathrm{d}}{\mathrm{dt}} \mathrm{p}_{1}=\frac{\mathrm{k}}{\mathrm{V}_{1}} \cdot\left(\frac{\mathrm{d}}{\mathrm{dt}} \mathrm{m}_{\mathrm{be}} \cdot \mathrm{R} \cdot \mathrm{T}_{\mathrm{be}}-\hat{\mathrm{P}}_{1} \cdot \mathrm{A}_{1} \cdot \frac{\mathrm{d}}{\mathrm{dt}} \mathrm{x}\right) \\
& \text { 2.hengertér } \quad \frac{\mathrm{d}}{\mathrm{dt}} \mathrm{p}_{2}=\frac{\mathrm{k}}{\mathrm{V}_{2}} \cdot\left(\tilde{\mathrm{F}}_{2} \cdot \mathrm{A}_{2} \cdot \frac{\mathrm{d}}{\mathrm{dt}} \mathrm{x}-\frac{\mathrm{d}}{\mathrm{dt}} \mathrm{m}_{\mathrm{ki}} \cdot \mathrm{R} \cdot \mathrm{T}_{\mathrm{ki}}\right) \\
& \text { mozgásegyenlet: } \quad \mathrm{p}_{1} \cdot \mathrm{A}_{1}-\mathrm{p}_{2} \cdot \mathrm{A}_{2}-\mathrm{m}_{\mathrm{g}} \cdot \mathrm{a}_{\mathrm{d}}-\mathrm{k} \cdot \mathrm{w}_{\mathrm{d}}-\mathrm{c} \cdot \mathrm{x}-\mathrm{F}_{\mathrm{s}}-\mathrm{F}_{\mathrm{t}}=0 \\
& \text { tömegáramlás: - beáramlás } \quad \frac{\mathrm{d}}{\mathrm{dt}} \mathrm{m}_{\mathrm{be}}=\mu_{\mathrm{f}} \mathrm{p}_{\mathrm{m}} \cdot \mathrm{A}_{\mathrm{fl}} \cdot \sqrt{\frac{2}{\mathrm{R} \cdot \mathrm{T}_{\mathrm{be}}}} \cdot \mathrm{w}_{\mathrm{be}} \\
& \text { - kiáramlás } \quad \frac{\mathrm{d}}{\mathrm{dt}} \mathrm{m}_{\mathrm{ki}}=\mu_{\mathrm{f}} \mathrm{p}_{\mathrm{at}} \cdot \mathrm{A}_{\mathrm{f} 2} \cdot \sqrt{\frac{\kappa}{R \cdot T_{\mathrm{ki}}}} \cdot \psi_{\mathrm{k}}
\end{aligned}
$$

A képletekben szereplő $Y_{b e}, Y_{k i}$ átömlési tényezőket a 1. és 2.ábrán látható fügvények szerint számíthatjuk.

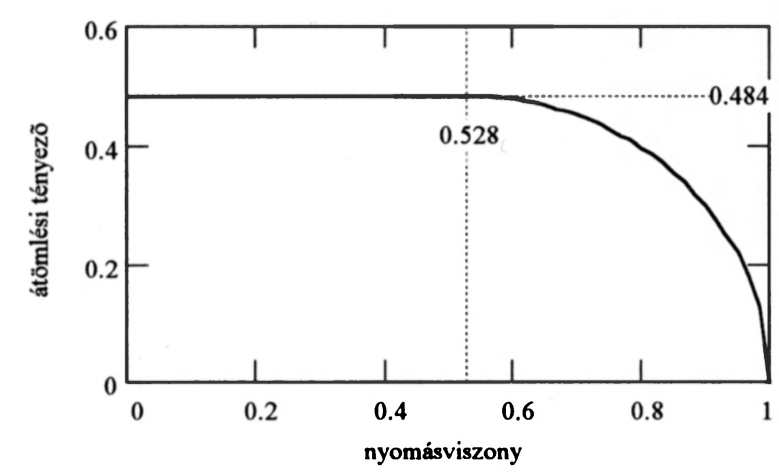

1.ábra: Zárt térbe áramlás esetén

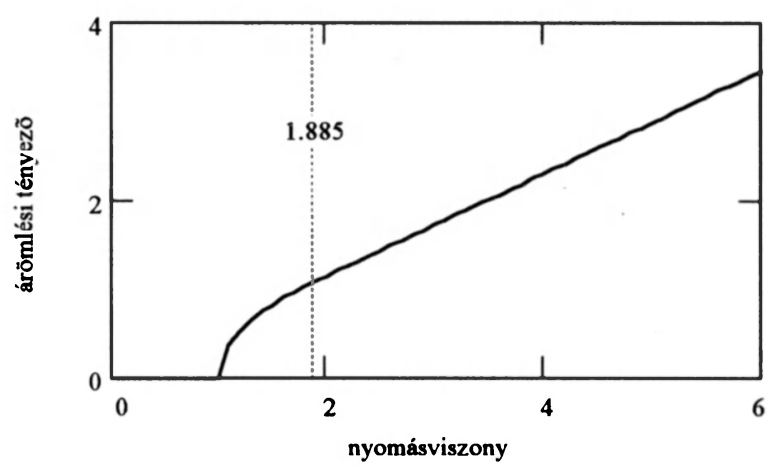

2.ábra: Atmoszférába áramlás esetén

A levezetések eredményeképpen egy differenciálegyenlet-rendszert kapunk, mely zárt alakban nem oldható meg csak numerikus úton. A numerikus módszerek (pl. Runge-Kutta módszer, Taylor módszer) megfelelő pontossággal le tudják kezelni az egyenleteket, azonban az átömlési függvények nagyon érzékenyek a peremfeltételekre. Annak érdekében, hogy meg tudjuk oldani a differenciálegyenleteket, a mozgás folyamatát több különböző (egymástól elhatárolt) szakaszra kell bontani: állandó tér (holttér) feltöltése, gyorsuló és egyenletes sebességü szakasz, löketvégi csillapitás szakasza, véghelyzetben tartózkodás, illetve a visszafütás szakasza. Az átömlési függvény érzékenysége miatt az egyes szakaszokon belül is különböző függvényeket kell alkalmazni. A differenciálegyenlet-rendszer bonyolultsága, a mozgásszakaszok nagy száma, valamint a numerikus módszer nagy müveletigénye miatt az eljárás csak számítógép segítségével 
valósitható meg. Végeredményként elmozdulás-idő, sebesség-idő, gyorsulás-idő és nyomás-idő függvényeket kapunk, amelyek maradéktalanul jellemzik a pneumatikus munkahenger dugattyújának viselkedését.

\section{Pneumatikus munkahengerek alkalmazása silók ürítésénél}

Speciális alkalmazási területe a pneumatikus munkahengereknek, az ömlesztett anyagok tárolására szolgáló silók ürítőnyílásai elzárószerkezeteinek mozgatása. Ezeknél az elzárószerkezeteknél a nyitás, illetve a zárás ideje alatt eltérően változnak a paraméterek. Az ömlesztett anyag viselkedésének ismeretében - a [5.] irodalom alapján - és az erōjátékok felírásával meg lehet határozni a terhelő erő változását a mozgás folyamán. Silóelzárók mozgatásánál a munkahenger terhelése az ürítőnyilás alakjától és méretétől, illetve a tárolt ömlesztett anyag nyomásától függ. A dugattyú terhelését az elzárólap felületére gyakorlot nyomás adja. A terhelt felület változása miatt változik a terhelő erő a mozgás folyamán, ezért az erőváltozás a dugattyú elmozdulás függvényeként adódik. Vizsgálatainkhoz függőleges kialakításu, téglalap kiáramlási keresztmetszetű silót választottunk, a dugattyú elmozdulását és sebességét a 5., 6.ábrán láthatjuk. Az elzárószerkezet elhelyezkedése és a dugattyú mozgása is függőleges, így a munkahenger terhelése a súrlódóerőkből, illetve az elzárólap és a dugattyú súlyából adódik.

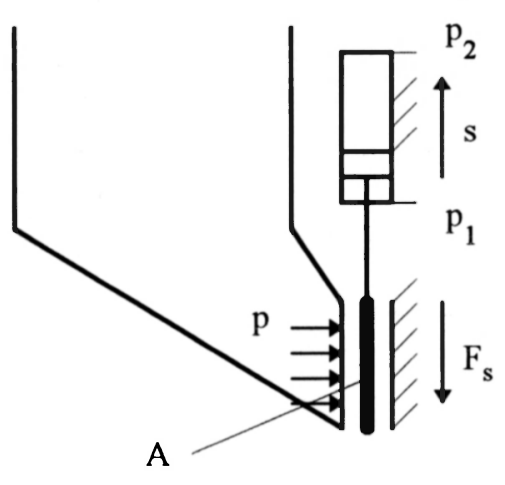

3.ábra: Függőleges kialakítás

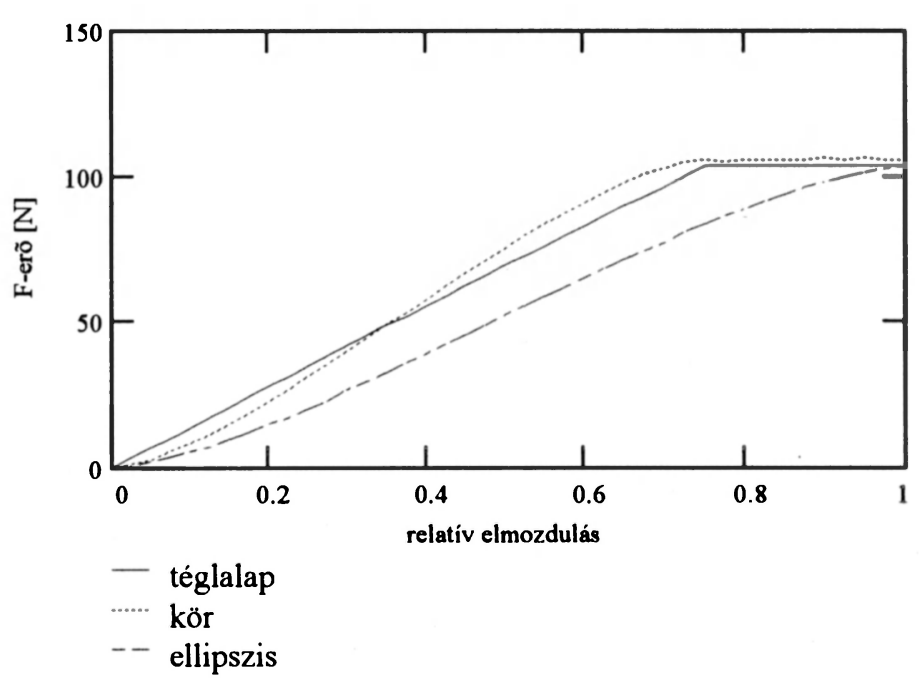

4.ábra: Az erők alakulása

különböző kiáramlási keresztmetszetek esetén 


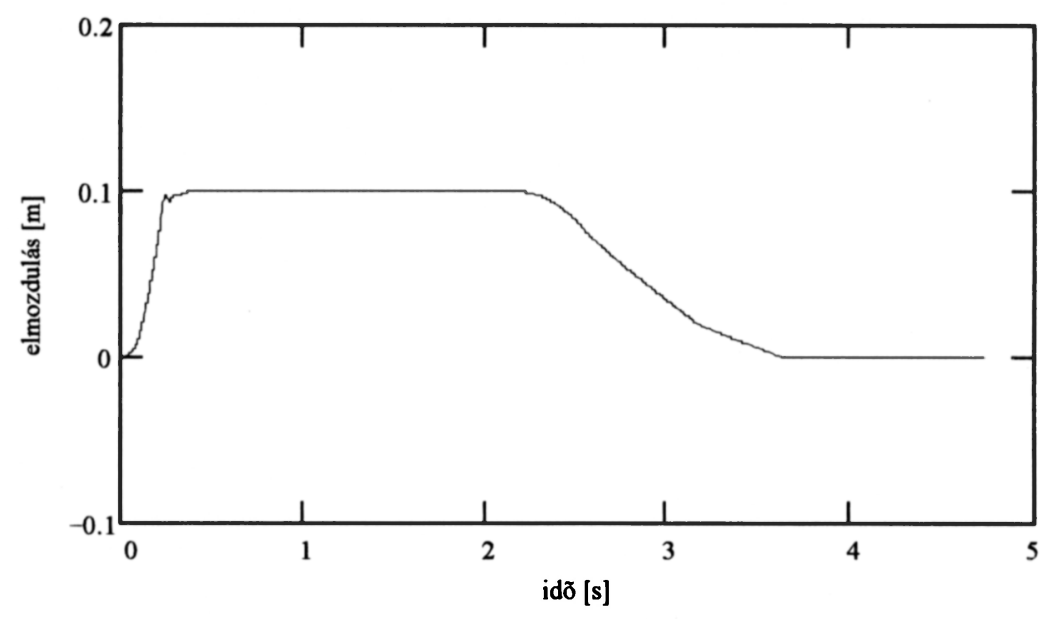

5.ábra

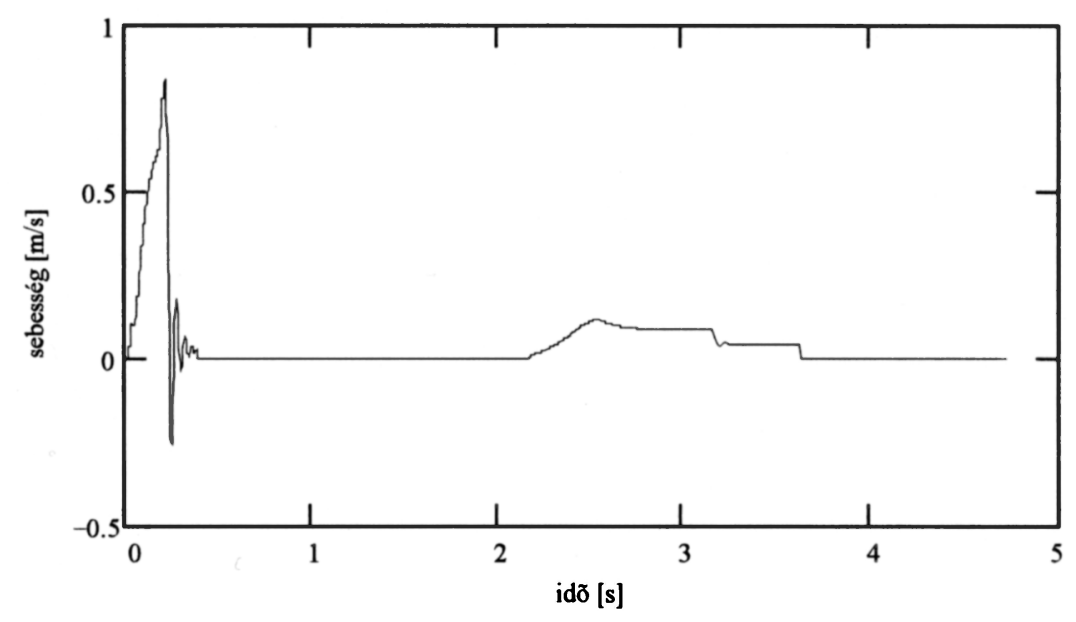

6.ábra

Mint az ábrákból is látható, az eljárás segítségével modellezni tudjuk a munkahenger dugattyújának - $\mathrm{s}$ ezáltal az elzáró-szerkezetnek is - a viselkedését a mozgás folyamán, szemléltetve a fellépő dinamikus jelenségeket, instacionárius hatásokat. Az elvégzett vizsgálatok lehetőséget adnak az optimális kialakitás kiválasztására, elsősorban a munkahenger egyenletes terhelésének figyelembevételével. Mindez azonban csak egy lehetséges alkalmazása az új méretező eljárásnak, a továbbiakban tervezzük a vizsgálatok kiterjesztését más felhasználási területekre is.

\section{Irodalomjegyzék:}

[1]. Dr. Elek I. - Hudáky J.: Az ipari pneumatika alapjai

(INTERPRESS Kiadó 1979)

[2]. Demeter Gy.: A pneumatika ipari alkalmazása

Müszaki Könyvkiadó, Budapest 1972.

[3]. Demeter Gy. - ifj. Kismarty L.: Pneumatikus rendszerek tervezése

Müszaki Könyvkiadó, Budapest 1974. 